\title{
Economic Empowerment of Poor Women With Grameen Bank Patterns on Baitul Mal Wa Tamwil Ibadurrahman
}

\author{
Dadang Husen Sobana*, Uus Ahmad Husaeni**
}

Received: 03.08 .2018

Accepted: 08.11.2018

DOI: $10.25272 /$ ijisef. 450600

Type: Research Article

\begin{abstract}
The purpose of this research is to analyze the contribution of Islamic microfinance with Grameen Bank pattern to economic empowerment and poverty alleviation to BMT Ibadurrahman members. This study uses a quantitative approach. Primary data collection techniques using a questionnaire. While secondary data comes from BMT annual reports (Baitul Mal wa Tamwil), journals, and other related literature. The sampling technique used is purposive sampling. The number of samples used were 100 female poor respondents of BMT Ibadurrahman members. The analysis technique used is the Spearman correlation. This study concludes that Islamic microfinance with the Grameen Bank pattern has a positive contribution to the economic empowerment of poor women. Financial capital and social capital are the keys to success in empowering the poor. Islamic microfinance with the Grameen pattern also has a significant relationship with poverty alleviation. This research also proves that poverty can be overcome if economic development is based on human development.
\end{abstract}

Keywords: Grameen Bank, Poverty, Economic Empowerment, Welfare and Spearman Correlation.

Jel Codes: G2, G21, P0

\footnotetext{
* Faculty of Sharia and Law, State Islamic University of Sunan Gunung Djati Bandung dadanghusensobana@uinsgd.ac.id, ORCID: https://orcid.org/0000-0002-0531-3431

** Faculty of Islamic Economic and Business, Suryakancana University, uusahmadhusaeni@unsur.ac.id, ORCID: https://orcid.org/0000-0002-3541-9245
} 


\section{Introduction}

The biggest problem in the field of economics lies in the problem of poverty. Poverty is multidimensional, because it includes social, cultural and even religious aspects (Ridwan, 2011). Poverty is a major problem affecting in Indonesia. Poverty is something that is created, something forced from the outside to someone. Therefore, poverty can be eliminated (Amalia, 2009). The effort that needs to be done to make the poor free from poverty is to create an environment for the poor to develop well. When the poor are able to utilize the energy and creativity they possess, poverty will disappear (Yunus \& Weber, 2011).

Complex poverty problems require joint and coordinated intervention of all parties. The handling, so far tends to be partial and unsustainable. For this reason, a systemic and comprehensive change is needed in efforts to reduce poverty (Kuncoro, 2013). Because poverty can endanger the faith and morals. Poor people can commit crimes because of urgent stomach needs.

According to Amalia (2009) one of the efforts to reduce poverty is by cutting off the poverty chain through empowering micro-enterprises and providing capital assistance. Capital loans for micro-enterprises are another form of social business that can eradicate poverty. Provision of Microfinance for the poor means that they can create their own jobs through selfemployment. Microfinance should be allocated with the aim of helping to realize social benefits in general as the source of funds of Microfinance is publicly owned (Chapra, 1985).

Opening employment means turning the unemployed people to be productive economic actors who can contribute their productivity (economic added value) to GNP (Gross National Product). The effort to eradicate poverty through micro-loans and by focusing on microenterprises have several reasons; micro-enterprises are part of the poor who have productive willingness and ability and, nationally, their portion is more than $90 \%$ compared to large-scale enterprises. In addition, micro-loans and micro-enterprises can absorb large labors where many women are empowered through this sector. Moreover, micro-enterprises can support the national economy (> 50\% of national GDP) (Amalia, 2009).

It has been more than 20 years since Indonesia had a Ministry of Cooperatives and Small and Medium Enterprises (CSMEs), supported by the obligations of banks to set aside $20 \%$ of total credit for MSMEs, and the obligation of SOEs to set aside some of their profits for the development of MSMEs. But this has not been met, because banks prefer to channel credits for consumption activities. Finally, MSMEs remain undeveloped. Poverty and unemployment seem to be eternal. In Bangladesh, since 1983, Muhammad Yunus has been pioneered the microcredit program and founded Grameen Bank. Grameen Bank is an institution specially designed for the capital provided for the poor. The Grameen system is an alternative solution for the poor not to become victims of the coveted loan sharks.

Long before Muhammad Yunus succeeded in alleviating poverty in Bangladesh with Grameen Bank and winning the Nobel Peace Prize in 2006, Amartya Sen had first undertaken a research on the causes of hunger, social imbalances, and poverty. The results of such research 
were written in "Poverty and Famines: An Essay on Entitlement and Deprivation' published by Oxford University Press in 1981, then Amartya Sen was awarded the Nobel Prize in Economics in 1998. This book influenced many international organizations and world countries in handling the food crises. Through the capability approach, Amartya Sen said that the main dimension in overcoming social imbalances and eradicating poverty were the enhancement of the individual's capacity, access to health and education, and increased income.

One of the efforts in reducing poverty is by cutting off the poverty chain through empowering micro-enterprises and providing capital assistance. Capital loans for micro businesses are another form of social business that can eradicate poverty. The provision of micro-loans for the poor aims to enable them to create their own jobs through self-employment. Microfinance should be allocated with the aim of helping to realize the general social welfare because microfinance sources are owned by the public (Chapra, 1985).

Poverty alleviation efforts through micro-loans and focus on micro-enterprises have several reasons, namely micro-enterprises are part of the poor who have the willingness and productive ability and nationally $90 \%$ more than large-scale businesses. In addition, microloans and micro-enterprises can absorb large employment, many women are empowered through this sector, and micro-enterprises can sustain the national economy ( $>50 \%$ of national GDP) (Amalia, 2009).

One effort to improve the ability of the poor is to give them opportunities to work and provide them with access to capital. In line with Amartya Sen's (1981) study, Shastri (2009) states that capital for micro-enterprises provided through micro finance is an effective tool to eradicate poverty and have a significant economic and social impact on the nation. Durrani (2011) added that microfinance is a tool that is very helpful to get prosperity and improve the social standards of the poor.

In Bangladesh, Yunus and Grameen Bank are able to organize communities to fight against poverty. Yunus and the poor are able to implement modern management and successfully build Bangladesh. As many as 97 percent of those who obtain micro loans and work in the SME sector are women's groups (Amalia, 2009).

The success of Yunus's micro-loan program in Bangladesh raised hopes that the Grameen Bank microcredit methodology could be applied almost universally. Between the late 1980s and the early 1990s, Yunus proved that the Grameen Bank idea could improve the lives of poor people around the world. Grameen Bank attracts people who have the potential to replicate this micro loan program (Yunus \& Jolis, 2010). Replication carried out in Malaysia and the Philippines has reaped a smooth road, and also in Indonesia there are now microfinance institutions that use the Grameen Bank system.

One of the microfinance institutions that uses the Grameen Bank system in Indonesia is the BMT Ibadurrahman, which was established in 2003. BMT, which operates with the Grameen system, has had 12,697 members as of July 2018. BMT Ibadurrahman uses the Grameen Bank 
system because in the distribution of Islamic micro loans it focuses on poor women, without collateral, small groups are created, group gatherings are routinely held, and use a joint responsibility system. Therefore, the contribution of sharia micro financing distributed by BMT Ibadurrahman with the Grameen system towards the economic empowerment of poor women to be free from poverty is very interesting to be studied and deserves further study.

The theory used in this study are: First, the theory of microfinance financing. Microfinance is at the forefront and shows the potential to alleviate poverty by providing microfinance to poor households. Indicators of microfinance programs are: (1) simple loan methodologies and no physical collateral; (2) using a joint responsibility system; (3) saving every week; (4) there are non-financial products, and (5) borrowers must have micro-businesses (Gera, 1999). Second, theories about the level of capability of members. According to Amartya Sen (1981), poverty occurs due to capability deprivation. Capability refers to two things, ability to do and ability to be. Capability reflects a person's ability to be functioning (doing or being). Capability level indicators, namely, (1) opportunities in the economic field; (2) opportunities in the social field; (3) opportunities in accessing health and being healthy; (4) opportunities in the field of education and being educated; (5) guarantee of openness; and (6) security guarantees. Third, the theory of poverty. The poverty indicators in this study used the Multidimensional Poverty Index (MPI) and also indicators with the BPS food poverty line (Sen, 1981). Three dimensions in the MPI and its indicators, namely (1) health: nutrition and infant mortality, (2) education: length of school, attendance in education, and literacy, and (3) quality of life: clean water, sanitation, lighting sources, materials cooking fuel, and home conditions.

\section{Method}

The population in this study were low-income women, members of BMT Ibadurrahman. Meanwhile, the number of samples in this study is 100 respondents from BMT members. For this reason, it is necessary to test the instrument before using it. The next step is to do a Validity Test, which shows the extent to which a measuring device measures what you want to measure. The questionnaire that is compiled must measure what it wants to measure. So, validity refers to the accuracy and accuracy of the test in carrying out its measurement function. The next step is used Reliability Test, which is to show the extent to which a measuring device can be trusted or reliable.

Data analysis techniques used in this study are using the Spearman Correlation Test. The Spearman correlation coefficient is used to measure closely the relationship between two variables. Spearman correlation test is a nonparametric test used for data with ordinal type. Based on Guilford's (1956) criteria, a good item is one that has a correlation coefficient above 0.200 .

\section{Results and Discussions}

The empowerment instrument used by BMT Ibadurrahman is Islamic microfinance. The financing program uses the Grameen pattern. This aims to make poor women in rural areas out of the poverty line. Amartya Sen (1983) asserts that poverty must be measured in the space 
of ability or capability and not just measured by the size of one's income (income poverty). Poverty is a multidimensional problem. For this reason, this study tries to see poverty from various dimensions, both from the adequacy of the economy, health, and education. This study measures poverty in a capability approach of BMT members.

\subsection{Microfinance, Capability and Poverty Levels of Members of BMT Ibadurrahman}

\subsubsection{Use of Islamic Microfinance}

Many studies have shown that microcredit has a positive effect and contributes significantly to poverty alleviation. The results of Abur and Torruam (2012) conclude that micro loans affect the poverty status of respondents and microfinance institutions are able to solve various problems and have helped reduce the poverty level of respondents. According to Bakhtiari (2006), microfinance can be an effective tool for alleviating poverty compared to other poverty alleviation programs. However, because poverty is a multidimensional and complex problem, the distribution and utilization must be careful so that the goal of poverty alleviation can be achieved.

This section describes a general description of microfinance and its use by poor women members of cooperatives, the level of capability they have, and the level of poverty experienced by members of cooperatives. Microfinance is not limited to the amount of rupiah lent to the poor to run micro businesses. Moreover, microfinance includes how loans are utilized and brings benefits, the ease with which they are offered, the increase in the amount of savings and income, and the success in economic empowerment. This is consistent with the statements of Anwarul Kabir, Suman Dey, and Shamsal Islam (2012), and Sadegh Bakhtiari (2006).

Furthermore, to know the picture of Islamic microfinance on BMT Ibadurrahman in general, can be seen in the following table:

Table 1. Description of Islamic Microfinance

\begin{tabular}{|c|c|c|c|}
\hline Score & Category & Frequency & Percentage \\
\hline $61-70$ & High & 40 & $40 \%$ \\
\hline $51-60$ & Medium & 42 & $42 \%$ \\
\hline $40-50$ & Low & 18 & $18 \%$ \\
\hline \multicolumn{2}{|c|}{ Amount } & 100 & $100 \%$ \\
\hline
\end{tabular}

Based on table 1 above, it is known that 42 BMT members received Islamic microfinance and benefited from the financing at a moderate level, and as many as 40 people at a high level. This can occur because of access to Islamic microfinance provided by the Ibadurrahman BMT to its members through a simple and easy procedure. However, in Islamic microfinance there is social capital and the advantages provided by cooperatives to its members, namely mentoring micro businesses, joint responsibility systems, not requiring physical collateral, providing educational funding loans, and financing life insurance. 
The first advantage of Islamic microfinance with the Grameen Bank pattern in BMT Ibadurrahman is that there is assistance and monitoring of micro businesses by BMT to each member. The second advantage is that regular weekly meetings are basically not only to fulfill the obligation to pay installments and save. In weekly meetings are also used to discuss the problems encountered during running a micro business. BMT Ibadurrahman field staff helped find a solution, even if there was still free time before going to the next center, a staff member took the time to visit the member's house and see the progress of his micro business. Islamic microfinance which is distributed by BMT Ibadurrahman is specifically for poor women, where they do not have valuables that can be used as collateral. In accordance with the opinion of Nowak (2008) that the difference between microfinance and conventional credit is on new targets, namely the poor and those who are rejected.

Poor people and those who are refused to get banking services and other financial institutions are caused by them being unbankable, not having collateral. Therefore, Islamic microfinancing with Grameen pattern is based on trust in the borrower's ability to achieve prosperity. In order to reduce the risk of non-performing financing, microfinance with the Grameen pattern uses a joint responsibility system.

According to Schreiner (2003), joint liability is a policy in which if a member of the group performs a default, it can lead to a loss of access to micro loans for all members within the group. Therefore, if there is a member who is unable to pay installments, the other members must pay the installments temporarily. This joint responsibility system can also reduce risk because joint responsibility provides encouragement to members to ensure that their colleagues do not waste loans obtained and give encouragement to persuade their colleagues not to pay in installments, even giving temporary bans on Unpaid loans. A joint liability is also useful for helping and helping the member who at the time of paying the installment is not economically capable and not because he is negligent. For this reason, members who are able to bail out in advance (suspension of loans that cannot afford) until the person is able to return. The joint system is like the kafalah principle in Islamic economics.

Kâfalah is a guarantee provided by a third party that he will bear the repayment of debtor's loan if the debtor is unable to pay off (due to bankruptcy). In the joint responsibility system, kafil (guarantor) is a fellow member in one group, while the ma'ful anhu is a member who can not afford to pay weekly installments. Therefore, if a member can not afford to pay the installment in a weekly assembly, then the other members of the group in the same group jointly pays the installment.

\subsubsection{Capability Level of Members of BMT Ibadurrahman}

With regard to poverty, as told by Sen (1983), poverty and hunger are not caused by food shortages, but because of lack of capacity and opportunities. Those who fall into poverty are caused by the inability to prosper. Many factors cause a person to lack the ability and opportunity to prosper, such as the level of education and health. The cost of educating children and very expensive health costs cannot be reached by the poor. Sen (1983), asserted 
that increasing the ability of individual poor people through access to education, health access, and respect for human rights, is a key dimension in efforts to overcome social inequality and eradicate poverty. A description of the level of capability of members of BMT Ibadurrahman can be seen in the following table:

Table 2. Capability Level of Members of BMT Ibadurrahman

\begin{tabular}{|c|c|c|c|}
\hline Score & Category & Frequency & Percentage \\
\hline $62-71$ & High & 28 & $28 \%$ \\
\hline $42-51$ & Medium & 54 & $54 \%$ \\
\hline $32-41$ & Low & 18 & $18 \%$ \\
\hline \multicolumn{2}{|c|}{ Amount } & 100 & $100 \%$ \\
\hline
\end{tabular}

Based on table 2 above, it is found that the majority of members of BMT Ibadurrahman (frequency of 54 people) have the capability level in the medium category. This means that most respondents have a pretty good level of capability. This happens because the key to improving the poor's capacity is to respect the rights of the poor and give them equal opportunities to develop their individual potentials. The poor are also human beings, so the environment in which they live should give them the opportunity to get a decent education and access to health, as upper-middle class people can freely obtain. Therefore, BMT Ibadurrahman provides opportunities for poor women to get access to finance for micro businesses. Starting from this access, it is expected to be a stepping stone so that they will have the ability to get education and health access. As many as 54 respondents have the level of capability currently in table 2, illustrating that the struggle of BMT Ibadurrahman was not in vain. The medium category means that it has increased from the low category, because BMT members who have become respondents have been at least 1 year of obtaining sharia microfinance and running a micro business. The BMT Ibadurrahman effort to empower poor women through Islamic microfinance services is a very good thing. This shows that women who previously only stayed at home and resigned to the economic crush, now they are working to be able to fight along with her husband to prosper the family.

Islamic microfinance is a financial capital or economic capital for poor women. The advantages of BMT Ibadurrahman with the Grameen Bank pattern are that members also get social capital. Because, BMT Ibadurrahman has financial products and social products. Some social products include independent, disciplined, and responsible. Social capital is something of value to poor women in remote villages because it makes them have bargaining power, dare to voice what they want. While independent is a major part of empowerment. The empowerment process aims to create independence, not dependence. If they are independent, those who are poor do not depend on anyone and in any form of assistance. This is in line with the statement of Nowak (2008), that the salvation of the poor does not lie in the hands of the rich who founded various charities and charities. Therefore, independence is very important for poor people to be able to get out of poverty that shackles it. Someone who does not have sufficient capability, then he will experience difficulties to be able to be fully independent. Whereas the capability itself comes from the opportunity given to the poor to develop their potential. One of them is 
by providing microfinance loans and providing opportunities for the poor to pursue micro businesses.

Three main things that become a benchmark for a person's capability level are education, health, and income. Although there are other things that are still debated in setting parameters of this level of capability. However, those three main things have been stated in the Human Development Index. Of the three things, a very important component is education. As Stamboel (2012) wrote, that the capability approach proposed by Amartya Sen emphasizes the intrinsic value of education, namely an opportunity, entitlement, and ways to improve the quality of life. With education, one will get more opportunities and wider choices. Through education also a person can determine the right choices, namely choices that can improve the level of welfare.

In line with what Stamboel mentioned above, BMT Ibadurrahman also shows his concern for the education of the children of mothers who are members of the cooperative. BMT provides education funding to children up to college. Whereas for children who have graduated from high school can work at BMT. Through education, it is hoped that children will not inherit poverty suffered by their parents. With higher education, they will have the ability to compete in the world of work and the ability to reach a more prosperous future. Whereas for their mothers (poor women members of BMT) who were illiterate, were given lessons on how to write and read by BMT Ibadurrahman field staff. At least each member can write names and signatures.

\subsubsection{Poverty Rate Member BMT Ibadurrahman}

Indicators for measuring poverty and welfare commonly used by the state, namely national income and per capita income, which should not be used anymore. Stamboel (2012) states that income per capita is nothing but a result of total national income to the population. This encourages countries to increase their production to be considered prosperous countries. In this process humans are considered as factors of production, equated with machines, soil, sand, gravel, and other production factors. This does not humanize humans at all. In Indonesia, so far the government's approach to overcoming poverty tends to the view that poverty is a matter of low per capita income or just looking at income poverty, regardless of the fact that poverty is a multidimensional problem. This resulted in the policy being carried out was oriented to the provision of cash assistance, both for poor families and poor villages.

The cash assistance is contained in the program of three poverty alleviation clusters launched by the government. Unconsciously cash assistance has caused poor people's dependence on the compassion of the government and others. The poor need more jobs. If there are no jobs to share, then the poor should be empowered to be able to open their own jobs. Microfinance is an important empowerment tool for women. They can be independent and ultimately can help themselves to get out of the cycle of poverty. Poverty level of cooperative members can be seen in the following table: 
Table 3. Poverty Rate Member BMT Ibadurrahman

\begin{tabular}{|c|c|c|c|}
\hline Score & Category & Frequency & Percentage \\
\hline $62-71$ & High & 28 & $28 \%$ \\
\hline $52-61$ & Medium & 53 & $53 \%$ \\
\hline $42-51$ & Low & 19 & $19 \%$ \\
\hline \multicolumn{2}{|c|}{ Amount } & 100 & $100 \%$ \\
\hline
\end{tabular}

Based on Table 3 above, it was found that most of the poverty levels of BMT members were in the medium category, with a total frequency of 53 people, followed by a low category of 19 people. This means that the struggle of BMT Ibadurrahman in the welfare of its members who are all poor women, has begun to show results. All respondents have at least been members of BMT for 1 year, so they have begun to be empowered and feel the benefits of Islamic microfinance. This happened because the efforts made by cooperatives in improving the welfare of poor households through empowering women had made poor women slowly rise from powerlessness.

BMT Ibadurrahman creates an environment where poor women live, allowing them to grow and prosper. Islamic microfinance is not a panacea that can cure poverty in an instant. Islamic microfinance also does not solve all development problems, but as Nowak (2008) notes, microfinance has shifted global knowledge and productivity, factors of production, infrastructure, water and land, health and education. This is more important to do than large projects that are not adapted to the conditions of the surrounding environment. Through microfinance, in addition to the equality of production factors, equality of opportunity to achieve a prosperous life is also accomplished.

For poor people, Islamic microfinance must be made as simple as possible in the aspects of the procedure and process of disbursement. For that, disbursement is enough with the approval of the husband and no collateral is needed. In addition, during weekly gatherings, there are always minor discussions regarding the development of micro businesses and the economic conditions of their families. They feel happy if their voice and complaints are heard and helped to find a solution. Small things like this contribute to the success of the empowerment process. Not necessarily that it is owned by other microfinance institutions, even banks do not even want to listen to the voices of poor people.

According to Matovu (2006) and Chambers (2011), people who are isolated from various kinds of access to development and fall into powerlessness are another form and another dimension of poverty. This means that what BMT Ibadurrahman does by reaching those who are marginalized to the corners of the country is very appropriate. Giving them access to microloans can make them feel valued and upheld as human beings. When poor people feel humanized, they feel happy and increase their enthusiasm to fight poverty. 


\subsection{Islamic Microfinance Relations and Capability Levels of Members of BMT Ibadurrahman with Poverty Alleviation}

\subsubsection{Islamic Microfinance Relationship with Poverty Alleviation}

The Islamic Microfinance rolled out by BMT Ibadurrahman has indicators that are adjusted to the Grameen pattern. Therefore, three main indicators are the process of distribution, the development of micro-enterprises, and non-financial products. Grameen patterned loans mean that Islamic microfinance uses the pattern as used by Grameen, namely group formation, attending weekly meetings, paying installments and weekly savings, and using a joint responsibility system. The development of micro businesses means that the cooperative has special attention to the sustainability of the business run by members. This is partly realized by business monitoring.

Besides loans, BMT with the Grameen pattern also has non-financial products as owned by Grameen Bank in Bangladesh. Some non-financial products provided by cooperatives to its members are discipline, independence, increasing bargaining power, and giving awareness of the importance of education. According to Schreiner (2003) in his Thesis stated that the most important non-financial services of the Grameen Bank system are social intermediaries, namely creating social capital for poor women as a by-product of weekly meetings.

BMT Ibadurrahman has tried to provide social capital. Poor women who previously had no "place" in the social environment, and even underestimated by her husband, now dare to discuss with her husband to express their opinions and wishes and ask for approval from him to be allowed to take part in the Islamic microfinance program. The poor women of today's BMT members have dared to take the decision to run a micro business for a more prosperous future. The Grameen-patterned Islamic microfinance relationship with poverty alleviation rates of members of BMT Ibadurrahman can be seen from the results of the Spearman correlation test as follows:

Table 4. Spearman Test Results Of Islamic Microfinance Variable with Poverty Alleviation Variable

\section{Correlations}

\begin{tabular}{|l|l|l|r|r|}
\hline & & & Islamic Microfinance & Poverty Alleviation \\
\hline \multirow{3}{*}{$\begin{array}{l}\text { Spearman's } \\
\text { Rho }\end{array}$} & Islamic & Correlation & 1.000 & .472 \\
& Microfinance & Coefficient & & \\
& & Sig. (2-tailed) &. & .000 \\
& $\mathrm{~N}$ & Correlation & $.472^{* *}$ & 100 \\
\hline & \multirow{3}{*}{ Poverty } & Coefficient & .000 & 1.000 \\
& Alleviation & Sig. (2-tailed) & 100 &. \\
& & $\mathrm{~N}$ & 100 \\
\hline
\end{tabular}

**. Correlation is significant at the 0.01 level (2-tailed). 
Based on the above table, it can be seen that Spearman correlation test results showed 0.472 results. That is, there is a micro-finance relationship with the level of poverty alleviation. This is in accordance with the reality on the ground which proves that Islamic microfinance brings considerable and real changes to the empowerment of poor women in rural areas. Islamic microfinance provides empowerment for women to gain a more prosperous life, by allowing them to take an active role in the development process and become the subject of development. As the subject of development, poor women play an active role in determining the future of children. The positive contribution of micro-loans to poverty alleviation is also stated by Shirazi and Khan (2009), from the results of his research concluded that micro-loans in Pakistan have reduced the national poverty rate by $3.07 \%$. The results are not large enough indeed, but if every year there continues to be a consistent reduction in the poverty rate, then most likely the dream of Muhammad Yunus to create a museum of poverty in the world will be achieved.

A positive relationship between Islamic microfinance and poverty alleviation of members of BMT Ibadurrahman if it runs consistently, there will be many poor people, especially women in rural areas who are empowered and out of poverty. With the same pattern of financing distribution and the same operating pattern of cooperative institutions, namely the Grameen pattern, poverty alleviation efforts at BMT Ibadurrahman began to show results.

After looking at the relationship between Islamic microfinance and poverty alleviation, the results of the significance test were then seen. The results of the significance test of Islamic microfinance relations with poverty alleviation in the table above can be seen from the value of Approx. Sig. ie 0.000 . This means that a significance value of 0.000 is smaller than alpha $5 \%$ or $0.000<0.05$. Thus, it can be concluded that Islamic microfinance with the Grameen pattern has a significant relationship with poverty alleviation. In line with this, Mansour and Chaouch (2013), revealed that Islamic microfinance is an effective alternative to achieving development goals. These goals include poverty alleviation and eradication of unemployment. This is because Islamic microfinance has provided loan capital for micro and small businesses, agriculture, and other small business people, especially projects in rural areas. Which of these efforts have so far not received sufficient access to capital services from various financial institutions.

Clement and Terande (2012), stated that the existence of microfinance institutions is able to make a real contribution in solving various problems in developing countries and has helped reduce poverty levels of borrowers. In developing countries, where most of the poor live, they need new breakthroughs to end poverty. For this purpose, BMT Ibadurrahman struggled to explore rural areas to hold hands on marginalized people who were rejected by banking services. Previously, the only financial access in the countryside was moneylenders. However, in reality, loan sharks can not improve their welfare. On the contrary, the cruelty of loan sharks makes the poor worse off. Interest charged by loan sharks to borrowers brings injustice and harm. 
In contrast to Islamic microfinance with a profit sharing system that brings justice to all parties and benefits. Islamic microfinance with the Grameen pattern has a significant relationship with poverty alleviation because it is motivated by the social justice aspect of Islamic microfinance. The side of social justice is indicated by the goals to be achieved are low-income communities and micro-entrepreneurs get top priority. Financing for micro entrepreneurs is used to develop businesses and strengthen capital to be able to compete with large traders (Shirazi and Khan, 2009). According to Nowak (2008), there needs to be equal opportunities prioritized with better access to factors of production and micro-loans are part of this. This equality of opportunity and equal distribution of mastery of production factors is pursued by the sharia microfinance program through the empowerment of the poor.

Contrary to this, Onwumere (2012) from the hypothesis he tested that microcredit in the Nigerian economy did not really help in alleviating poverty but what happened was an increase in human capital. This means that microcredit in Nigeria has a non-significant impact on poverty alleviation and has a significant (positive) impact on human capital development. Agreeing with Onwumere, Chowdhury (2009) stated that microfinance develops several business strategies and has an impact on poverty reduction still in doubt. Because, microfinance is only one aspect of the many support needed by micro-enterprises. Other aspects needed are training, skills, and access to marketing information. Matovu (2006) also expressed doubts about the role of microfinance for poverty alleviation. According to him, poverty alleviation by microfinance is like a drop of water in the ocean, very small. He added that microfinance only knows limited to the symptoms of poverty, not on the causes of poverty, and that which has not developed well until now is the empowerment of women with the help of microfinance. Meanwhile Imai (2010), states that some evidence creates black spots on microfinance. Much microfinance research has been shown to have a negative impact on women's empowerment. If women do not have the same portion as men to get microfinance facilities, then society can not control poverty.

\subsubsection{Relationship between Capability Levels of Members of BMT Ibadurrahman and Poverty Alleviation}

Poverty is identified as capabilities deprivation, which is the loss of something that is intrinsically very important because it causes a person's ability to give value to their life by their "doings" and "beings" (Stamboel (2012). Therefore, the capability becomes one of the variables that needs to be included in this study because the capability approach emphasizes the multidimensional nature of analyzing poverty problems. This approach has broader authority than poverty which is only measured by income poverty (Hick, 2012). BMT Ibadurrahman with poverty alleviation can be known by looking at Spearman correlation test results in the following table: 
Table 5. Spearman Test Results Level Capability Variable of Members with Poverty Alleviation Variable

\section{Correlations}

\begin{tabular}{|c|c|c|c|c|}
\hline & & & Level Capability & Poverty Alleviation \\
\hline \multirow{8}{*}{$\begin{array}{l}\text { Spearman's } \\
\text { Rho }\end{array}$} & & Correlation & 1.000 & .632 \\
\hline & Level & Coefficient & & \\
\hline & Capability & Sig. (2-tailed) & & .000 \\
\hline & & $\mathrm{N}$ & 100 & 100 \\
\hline & & Correlation & $.632^{* *}$ & 1.000 \\
\hline & Poverty & Coefficient & & \\
\hline & Alleviation & Sig. (2-tailed) & .000 & \\
\hline & & $\mathrm{N}$ & 100 & 100 \\
\hline
\end{tabular}

**. Correlation is significant at the 0.01 level (2-tailed).

Based on the Spearman test results table above, it can be seen the correlation value is 0.632 . This means that there is a relationship between the level of capability of members and poverty alleviation. A positive relationship between the level of capability of BMT members on poverty alleviation is inseparable from Islamic microfinance services. Because, thanks to Islamic microfinance, cooperative members have more opportunities, opportunities, and choices to try to improve their welfare. Opportunities, opportunities and choices can improve capabilities, which capability has an important role in determining a person's level of welfare. So, the poor must be empowered to become capable humans, and can get out of the poverty trap.

The opportunities and opportunities provided by BMT Ibadurrahman are to open and develop Islamic micro businesses. Since the poor live in rural areas, the businesses that are run are not only trading, but also farming and raising livestock. Revenues from various types of businesses strengthen the economics of members' families, so they can make choices that are valuable to their lives. These options include the choice to pay for their children's schooling to college, choices for healthy living, and the choice to meet the family's nutritional needs by serving nutritious meals.

Education and health are two of the most basic things that everyone must meet. Both of these are also the rights of the poor to obtain them. If that can not be achieved by the poor, then their basic ability has been seized. This is consistent with what Hick (2012) writes about Amartya Sen's thinking that the perspective of capability views poverty as a deprivation of basic ability. Like physical deprivation, namely nutritional adequacy.

The relationship between the level of capability with poverty alleviation can be seen from the significance value in table 5 above. Based on the table, the significance value is 0,000 . Thus, a significance level of 0.000 is smaller than the alpha of $5 \%$ or $0.000<0.05$. So it can be concluded that the level of member capability does have a significant relationship to poverty alleviation. 
This reinforces Stamboel's (2012) statement, that the higher the basic capability it has, the higher the chance to increase its potential. In line with Stamboel, Sumodiningrat (2009) says that the more abilities he possesses, the greater his freedom to make choices that are of value to one's well-being.

Stamboel's (2012) and Sumodiningrat (2009) statements mean that one's capability affects the level of welfare. It also means that the higher the capability or ability of a person, the higher the poverty rate will decrease. Therefore, the effort to end poverty that is multidimensional is to give equal opportunities to the poor to access various services (capital, health, education) and factors of production. Those who can not access the factors of production are not capable or powerless. Thus, the struggle to alleviate poverty begins with the empowerment of the poor.

The significant relationship between the level of capability of cooperative members and poverty alleviation can not be separated from the role of BMT Ibadurrahman. BMT Ibadurrahman has been trying to provide opportunities and options for poor mothers to get Islamic micro financing because mothers play a big role in the development and future of their children. BMT Ibadurrahman also invites poor women who are members to apply for an education funding loan and this is for the future of the children of the poor.

This is a process of human development in order to become a capable human, so that it has a high level of capability. Felton Earls, a professor at Harvard University stated that the core of Amartya Sen's capability theory is that every society has a responsibility to develop programs for every citizen, especially children, so that they can achieve maximum fulfillment and develop into capable human beings. It emphasizes that human development is important to create capable people, so that they are able to choose decisions that are good for their lives, by doing things (doings) or becoming things (beings). In this case, BMT Ibadurrahman has tried to help poor women to turn into capable human beings (Julianto, 2007).

\subsection{Role of Islamic Microfinance and Capability of Members of BMT Ibadurrahman Against Poverty Reduction}

Islamic microfinance has a relationship with poverty alleviation, with a correlation value of 0.472. While the level of member cooperative capability has a relationship with poverty alleviation, with a correlation value of 0.632 . Thus, the relationship that is owned by the level of capability of members of the cooperative (value: 0.632 and significance of 0.000 ) with poverty reduction is greater than the relationship of sharia microfinance (value: 0.472 and significance of 0.000 ) with poverty alleviation. Islamic microfinance and the capability level of cooperative members have a significant relationship to poverty alleviation. This means that if the utilization of sharia microfinance is getting better and the level of capability of BMT Ibadurrahman members is getting higher, then the chances of success in poverty alleviation are even greater. Islamic microfinance is an instrument of empowerment, a tool to provide opportunities and choices for the poor so that they can be independent and become capable humans. Being a capable human being, enabling him to have a higher level of welfare. 
Capability is the basic ability of every human being. Thus, the cause of poverty measured in the space of ability is reduced or loss of one's capability. Therefore, to alleviate the poor from poverty is to increase their capabilities so that they can help themselves and not fall into poverty. This is in accordance with the statement of Huraerah (2008), which reveals several strategies that must be done to overcome poverty, among others by increasing capacity and encouraging productivity. The strategy that must be chosen is to increase the basic capacity of the poor to increase income through measures to improve access to health and education services, increase business skills, technology literacy, network expansion and market information.

The degree of capability is the basic ability of the poor to "doings" and "beings". Naturally, if the capability level is stronger influencing one's welfare compared to other variables (Islamic microfinance), because it is directly related to life choices. People who cannot afford to doings and beings cannot certainly have choices to live a more prosperous life. However, the position of microfinance of sharia still has an important role in the process of poverty alleviation. Because, access to Islamic micro financing with the Grameen pattern has a dimension of social justice and alignments for the poor and marginalized. This is evidenced by the Islamic microfinancing system in BMT Ibadurrahman siding with the poor; without collateral, using a system of joint responsibility, social capital transfers, business monitoring, and special attention to the mothers of cooperative members by providing loans for education funds and employment opportunities for these children at the BMT Ibadurrahman institution.

Wijono (2005) confirms that loan in the form of capital for micro-enterprises is one of the most powerful efforts in dealing with poverty. It is based on the fact that there are differences in classification which include: (1) the extreme poor, those who are unpaid and do not have productive activities, (2) the community in the poor category but with productive activities economically active working poor, (3) low income people, those who have income but few. The approach used in poverty alleviation for the first poor will be more appropriate if direct approaches are used, such as food and subsidy programs. As for the second and third poor groups, more effective use of indirect approaches such as creating a climate conducive to the progress of micro enterprises and the development of various types of micro loans for SMEs.

Based on Wijono's (2005) classification of the above groups of poor people, the economic empowerment carried out by BMT Ibadurrahman through the provision of Islamic microfinance is on the classification of the poor, economically active working poor and lower income. BMT Ibadurrahman provides loans to poor women not for free or no obligation to return. For that, each member or family of the member concerned must have a micro business, both in agriculture, animal husbandry, or trade. However, even though they have businesses, they are still in the economically active working poor category because all basic needs have not been met (including education and health). In addition, most of them are still lower income. 
According to Wijono's opinion (2005) above, micro-loans are not suitable for those who are very poor, on the grounds that they need direct assistance. However, the BMT Ibadurrahman with the Grameen Bank pattern is not. Islamic microfinance from BMT Ibadurrahman reaches out to all the poor, even very poor communities. Khaled and Farhana (2011), citing Muhammad Yunus's statement that the more a person is in a state of deprivation, he is the more attractive (for Grameen Bank). If someone has nothing at all, then he will get the highest priority (from Grameen Bank). The main priority is given to poor people who do not own land and other valuable assets, do not have fixed income, and people who are in vulnerable conditions.

\section{Conclusion}

This study concludes that Islamic microfinance with the Grameen Bank pattern has a positive contribution to the economic empowerment of poor women and alleviation of rural poverty. The success of empowerment is due to the strengthening of financial capital and social capital for poor women. Social capital becomes the guarantor factor for the sustainability of empowerment program with Grameen Bank pattern. A distinctive feature of the successful empowerment of poor women is the increasing number of weekly women's income, growing independence in the fields of food, health, and education.

This study also proves that poverty can be overcome if economic development is based on human development. Human development is done through empowerment. Financial capital and social capital are the keys to success in empowering the poor. This is based on the results of the Spearman correlation test which shows that the level of capability (ability of HR) of cooperative members has a significant relationship with poverty alleviation. The facts on the ground show that microfinance program with Grameen Bank system is very helpful for poor women in empowering themselves.

The next contribution, which is very important in its role in poverty alleviation is to improve the capabilities of the poor. BMT Ibadurrahman provides opportunities, opportunities, and trust to poor women to strive for prosperity. BMT Ibadurrahman seeks to improve the capabilities of the poor by humanizing humans and breaking dependence. The rural poor are marginalized and excluded. Thus, giving them access to venture capital is very valuable.

The results of this study reinforce the research results Shirazi and Khan (2009) which concluded that micro-loans in Pakistan have reduced the national poverty rate by $3.07 \%$. It also supports Shastri's (2009), Muhammad Yunus (2008), Chowdhury (2008), Kabir (2012), Durrani (2011), Mansour and Chaouch (2013) statements, proving that microfinance creates self-employment opportunities that have an impact on poverty alleviation and unemployment. This study also strengthens the opinion of Amartya Sen (1981), Frediani (2007) and Robeyns (2003) which states that the level of capability (basic ability) of a person associated with the level of poverty he experienced. Meanwhile, this study differs from the conclusions shown by Onwumere (2012), Matovu (2006) and Chowdhury (2009) stating that microfinance has an insignificant impact on poverty alleviation. This study also does not 
match the results of Imai's (2010) research, that microfinance creates black spots, because women do not share the same portion as men, so that people can not control poverty.

\section{References}

Abur, C.C., \& Torruam, J.T. (2012). Microcredit as a Strategy for Poverty Reduction in Makurdi Local Government Area of Benue State, Nigeria. International Journal of Humanities and Social Science, 2, 179-186.

Amalia, E. (2009). Keadilan distributif dalam ekonomi islam: penguatan peran LKM dan UKM di Indonesia. Jakarta: Raja Grafindo Persada.

Bakhtiari, S. (2006). Microfinance and Poverty Reducing: Some International Evidence. International Business and Economic Research Journal, 5, 65-71.

Chapra, Umer. (2001). The Future of Economics: An Islamic Perspective (Lanskap Baru Perekonomian Masa Depan) (Sigit Pramono, Penerjemah). Jakarta: SEBI.

Chapra, U. (1985). Towards a just monetary system. London: The Islamic Foundation.

Chowdhury, A. (2009). Microfinance as A Poverty Reduction Tool: A Critical Assessment. Department of Economic and Social Affairs (DESA) Working Paper, 89, 1-12.

Chowdhury, M.J.A. (2008). Poverty and Microfinance: An Investigation into The Role of Microcredit in Reducing the Poverty Level of Borrowing Households in Bangladesh and The Philippines. The Whitehead Journal of Diplomacy and International Relations, 7, 1935.

Durrani, M.K.K. (2011). Role of Microfinance in Reducing Poverty: A Look at Social and Economic Factors. International Journal of Business and Social Science, 2, 138-144.

Ridjaluddin, F.N. (2007). Nuansa-nuansa ekonomi islam. Jakarta: Sejahtera.

Gera, N. (2009). Book Review: Muhammad Yunus with Alan Jolis, Banker to the Poor, The Story of Grameen Bank. The Lahore Journal of Economics, 14, 173-175.

Hick, R. (2012). The Capability Approach: Insights for a New Poverty Focus. London School of Economics and Political Science, Journal of Social Policy, 5, 1-18.

Huraerah, A. (2008). Pengorganisasian dan pengembangan masyarakat; model dan strategi pembangunan berbasis kerakyatan. Bandung: Humaniora.

Imai, K.S. (2010). Microfiance and Poverty: A Macro Perspective. Research Institute for Economic and Business Administration Kobe, University Japan, 5, 1-45.

Islam, T. (2007). Microcredit and poverty alleviation. England: Ashgate Publishing Limited.

Guilford, J.P. (1956). Fundamental statistic in psychology and education. New York: McGrawHill Book Company, Inc. Gul.

Julianto, I. (2008). Amartya sen dan nobel bagi kaum papa "Esai-Esai Nobel Ekonomi". Jakarta: Kompas Media Nusantara. 
Kabir, M.A. (2012). The Role of Microcredit and Microfinance Institutions (MFIs): Extent and Intensity of Poverty, Poverty Alleviation and Outreach. International Affairs and Global Strategy, No. 4, 29-48.

Khotimah, K. (2009). Diskriminasi Gender Terhadap Perempuan dalam Sektor Pekerjaan. Jurnal YINYANG: Studi Gender dan Anak, 4, 158-180.

Kuncoro, M. (2013). Mudah memahami dan menganalisis indikator ekonomi. Yogyakarta: UPP STIM YKPN.

Kusumo, R.A.B. (2008). Analisis Peran Gender Serta Hubungannya dengan Kesejahteraan Keluarga Petani Padi dan Hortikultura di Daerah Pinggiran Perkotaan. Jurnal Media Gizi dan Keluarga, 32, 52-64.

Mansour, M., \& Chaouch, T.B. (2013). Dawr al-Tamwîl al-Aṣghar fî Muhârabah al Faqr fî alManâtiq al-Rîfiyah Ḍamina Uțur alMâliyah al-Islâmiyah. Mawsû́eah al-Iqtiṣâd wa alTamwîl al-Islâmy, 4, 23-35.

Matovu, D. (2006). Microfinance and Poverty Alleviation Uganda. Africa and International Development Cooperation, 6, 1-64.

Mehta, C.R., \& Patel, N.R. (2010). IBM SPSS Exact Tests. Cambridge: Cytel Software Corporation.

Nowak, M. (2008). Revolusi kredit mikro: dimana pinjaman bukan hanya untuk yang kaya. Jakarta: Dian Rakyat.

Onwumere, J.U.J. (2012). The Impact of Microcredit on Poverty Alleviation and Human Capital Development: Evidence from Nigeria. European Journal of Social Review, 28, 416-423.

Partomo, T.S. (2013). Ekonomi koperasi. Bogor: Ghalia Indonesia.

Purwoto, A. (2007). Panduan lab statistik inferensial. Jakarta: Grasindo.

Putri, A.D., \& Setiawina, N.D. (2013). Pengaruh Umur, Pendidikan, Pekerjaan Terhadap Pendapatan Rumah Tangga Miskin di Desa Bebandem. E-Jurnal Ekonomi Pembangunan Universitas Udayana, 2, 173-180.

Kaplan. R. M.. \& Saccuzzo D.P. (1993). Psychological testing principles, application, and issues. California: Brooks/Cole Publishing Company.

Rahman, R., \& Nie, Q. (2011). The Synthesis of Grameen Bank Microfinance Approaches in Bangladesh. Elsevier-International Journal of Economics and Finance, 3, 207-218.

Ratnawati, S. (2011). Model Pemberdayaan Perempuan Miskin Perdesaan Melalui Pengembangan Kewirausahaan. Jurnal Kewirausahaan, 5, 21-35.

Ridwan, M. (2011). Manajemen baitul maal wa tamwil (BMT). Yogyakarta: UII Press. 
Rochaety, E. (2009). Metodologi penelitian bisnis dengan aplikasi SPSS. Jakarta: Mitra Wacana Media.

Santoso, S. (2012). Aplikasi SPSS pada statistik non parametik. Jakarta: Elex Media Komputindo.

Schreiner, M. (2003). A Cost-Effectiveness Analysis of the Grameen Bank of Bangladesh. Development Policy Review, 21, 357-382.

Sen, A. (1981). Poverty and famines: an essay on entitlement and deprivation. New York: Oxford University Press.

Shastri, R.K. (2009). Microfinance and Poverty Reduction in India: A Comparative Study with Asian Countries. African Journal of Business Management, 4, 136-140.

Shirazi, N.S., \& Khan, A.U. (2009). Role of Pakistan Poverty Alleviation Funds (PPAF) Micro Credit in Poverty Alleviation. Pakistan Economic and Social Review, 47, 215-228.

Shukran, K., \& Rahman, F. (2011). A Grameen Bank Concept: Microcredit and Poverty Alleviation Program in Bangladesh. International Conference on Emerging Trends in Computer and Image Processing (ICETCIP), 47-51.

Singarimbun, M., \& Effendi, S. (2008). Metode penelitian survai. Jakarta: Pustaka LP3ES Indonesia.

Stamboel, K.A. (2012). Panggilan keberpihakan: strategi mengakhiri kemiskinan di Indonesia. Jakarta: Gramedia Pustaka Utama.

Sumodiningrat, G. (2009). Mewujudkan kesejahteraan bangsa: menanggulangi kemiskinan dengan prinsip pemberdayaan masyarakat. Jakarta: Elex Media Komputindo.

Supranto, J. (2009). Statistik teori dan aplikasi. Jakarta: Erlangga.

Swastika, D.K.S. (2011). Membangun Kemandirian dan Kedaulatan Pangan untuk Mengentaskan Petani dari Kemiskinan. Jurnal Pengembangan Inovasi Pertanian, 4, 103117.

Suyanto, B. (2001). Kemiskinan dan Pemberdayaan Masyarakat Miskin. Jurnal Masyarakat, Kebudayaan, dan Politik, 14, 25-42.

Tanjung, H., \& Devi, A. (2013). Metodologi Penelitian Ekonomi Islam. Jakarta: Gramata Publishing.

Widyasworo, R. (2013). Analisis Pengaruh Pendidikan, Kesehatan, dan Angkatan Kerja Wanita Terhadap Tingkat Kemiskinan di Kabupaten Gresik (Studi Kasus 2008-2012). Jurnal Ilmiah Mahasiswa Fakultas Ekonomi dan Bisnis Universitas Brawijaya, 6, 219-229.

Wijono, W.W. (2005). Pemberdayaan Lembaga Keuangan Mikro Sebagai salah satu Pilar Sistem Keuangan Nasional: Upaya Konkrit Memutus Mata Rantai Kemiskinan. Kajian Ekonomi dan Keuangan, 5, 86-100. 
Yunus, M., \& Jolis, A. (2010). Banker to the poor: the story of the grameen bank. London: Aurum Press Ltd.

Yunus, M. \& Weber, K. (2011). Building social business: the new kind of capitalism that serves humanist Most Pressing Needs. New York: Public Affairs.

Yunus, M. (2011). Vision 2050: A Poverty-Free World. Social Business A Step Toward Creating A New Global Economic Order. The Journal of Social Business: Social Business and New Economics Paradigm, 1, 7-23. 